\title{
Diet selection of pigs and poultry
}

\author{
BY S. P. ROSE \\ Harper Adams College, Newport, Shropshire TF10 8NB \\ I. KYRIAZAKIS \\ Edinburgh School of Agriculture, West Mains Road, Edinburgh EH9 $3 J G$
}

The majority of animals in the wild are able to select a diet most suited to their needs by choosing between a wide variety of feedstuffs (Rozin, 1976; Krebs \& Davies, 1981). Natural selection has probably favoured those individuals within these species who forage more efficiently and so their genes have dominated in the population (Dawkins, 1989). Recent advances in ...the selection of domesticated pigs and poultry have profoundly changed their productive performance, but it is unlikely that their ability to select an adequate diet has been significantly altered in relation to the rigorous selection which had operated on the wild ancestor for thousands of years.

Experimental evidence shows that domesticated pigs and poultry are able to select an adequate diet when they are given a wide selection of feedstuffs. When broilers were given a choice of nine different feedingstuffs from 4 to 9 weeks of age (Ahmed, 1984), in the last 3 weeks of the growth period they selected a diet which provided a nutrient intake similar to their published requirements (National Research Council, 1984; Table 1). Evvard (1915) gave growing pigs a choice of seven feedstuffs. The pigs grew exceptionally well compared with their expected growth potential.

Table 1. Diet selection of broilers ( $6-9$ weeks) given a choice of nine feedingstuffs*

\begin{tabular}{|c|c|c|}
\hline Feedingstuff & & $(g / k g)$ \\
\hline Ground wheat & & 625 \\
\hline Ground barley & & 192 \\
\hline Maize oil (plus sawdust) & & 49 \\
\hline White-fish meal & & 117 \\
\hline Meat-and-bone meal & & 15 \\
\hline Soya-bean mcal & & 9 \\
\hline Dicalcium phosphate & & 0.7 \\
\hline Salt & & 0.2 \\
\hline \multirow[t]{2}{*}{ Vitamin and mineral premix } & & 0.2 \\
\hline & & $100 \cdot 0$ \\
\hline Calculated composition $(\mathrm{g} / \mathrm{kg})$ & Selected diet & $\begin{array}{l}\text { Nutrient } \\
\text { requirements }\end{array}$ \\
\hline Metabolizable energy $(\mathrm{MJ} / \mathrm{kg})$ & $12 \cdot 5$ & 13.4 \\
\hline Crude protein & $17 \cdot 7$ & $18 \cdot 0$ \\
\hline Lysine & 0.87 & 0.85 \\
\hline Methionine & 0.61 & 0.60 \\
\hline Calcium & 1.05 & 0.80 \\
\hline Phosphorus & 0.80 & 0.50 \\
\hline
\end{tabular}

* Values adapted from Ahmed (1984) and nutrient compositions calculated, and requirements recommended by National Research Council (1984). 
Table 2. Protein intakes and performance of growing pigs given a choice of two foods differing in protein content*

\begin{tabular}{|c|c|c|c|}
\hline \multicolumn{2}{|c|}{$\begin{array}{l}\text { Protein contents of foods } \\
(\mathrm{g} / \mathrm{kg})\end{array}$} & \multirow{2}{*}{$\begin{array}{l}\text { Protein intake } \\
\quad(g / \mathrm{kg})\end{array}$} & \multirow{2}{*}{$\begin{array}{l}\text { Live-wt gain } \\
\text { (g/d) }\end{array}$} \\
\hline 1 & 2 & & \\
\hline 125 & 213 & 208 & 752 \\
\hline 125 & 267 & 204 & 768 \\
\hline 174 & 213 & 202 & 769 \\
\hline 174 & 267 & 205 & 763 \\
\hline & & 11 & 54 \\
\hline
\end{tabular}

SED, standard error of difference.

* Values from Kyriazakis et al. (1990).

Modern pig and poultry enterprises can only practically offer the stock a choice of two or three feeds, so most studies have concentrated on the selection between a limited number of feeds. In situations with limited choice the type of feeds offered must satisfy a number of conditions: (1) the combination of feeds must be non-limiting. A combination of feeds which are all below the requirement for one or more nutrients will interfere with the dietary selections (Holcombe et al. 1976; Savory, 1979; Kyriazakis et al. 1990); (2) there must be a free, continuous and undisturbed access to all foods; (3) none of the feeds has significant amounts of anti-nutritive factors.

When pigs and poultry are given a suitable choice between two feeds that meet the previously-stated specifications there is substantial evidence that they can select a diet that meets their apparent requirements. Kyriazakis et al. (1990) gave pigs a choice of four different pairs of feeds, one above and one below their crude protein (nitrogen $\times 6 \cdot 25$ ) requirements. There was no complete avoidance of any of the four feeds across treatments but the proportion chosen as one feed varied systematically with the composition of the other feed given. This mode of diet selection resulted in similar amounts of crude protein selected by all pigs and similar growth rates (Table 2). S. P. Rose (unpublished results) compared growing pigs given a choice of a high-energy, low-protein feed (ground wheat) with a nutrient-dense but low-energy feed with pigs given a complete single feed. The energy and crude protein intakes of the two groups of pigs were remarkably similar over a 5-week growth period (Fig. 1). Similar comparisons have been made with choice-fed poultry and studies with laying hens (Kiiskinen, 1987), replacement pullets (Scott \& Balnave, 1989), growing broilers (Sinurat \& Balnave, 1986) and growing turkeys (Rose \& Michie, 1982) have shown an ability to select betwe:en two or three feedstuffs to obtain a nutrient intake which matches their requirements.

\section{EFFECTS OF NUTRITIONAL REQUIREMENTS}

The nutrient requirements of pigs and poultry are a major factor in determining their diet selections. Brody et al. (1984) selected two lines of chickens for either slow or fast live-weight gains. Birds from both lines were given the choice of a low-protein, highcnergy feed and a high-protein, low-energy feed. The birds from the fast live-weight gain line, with probably a greater requirement for protein, selected a higher proportion of protein in their diet. 

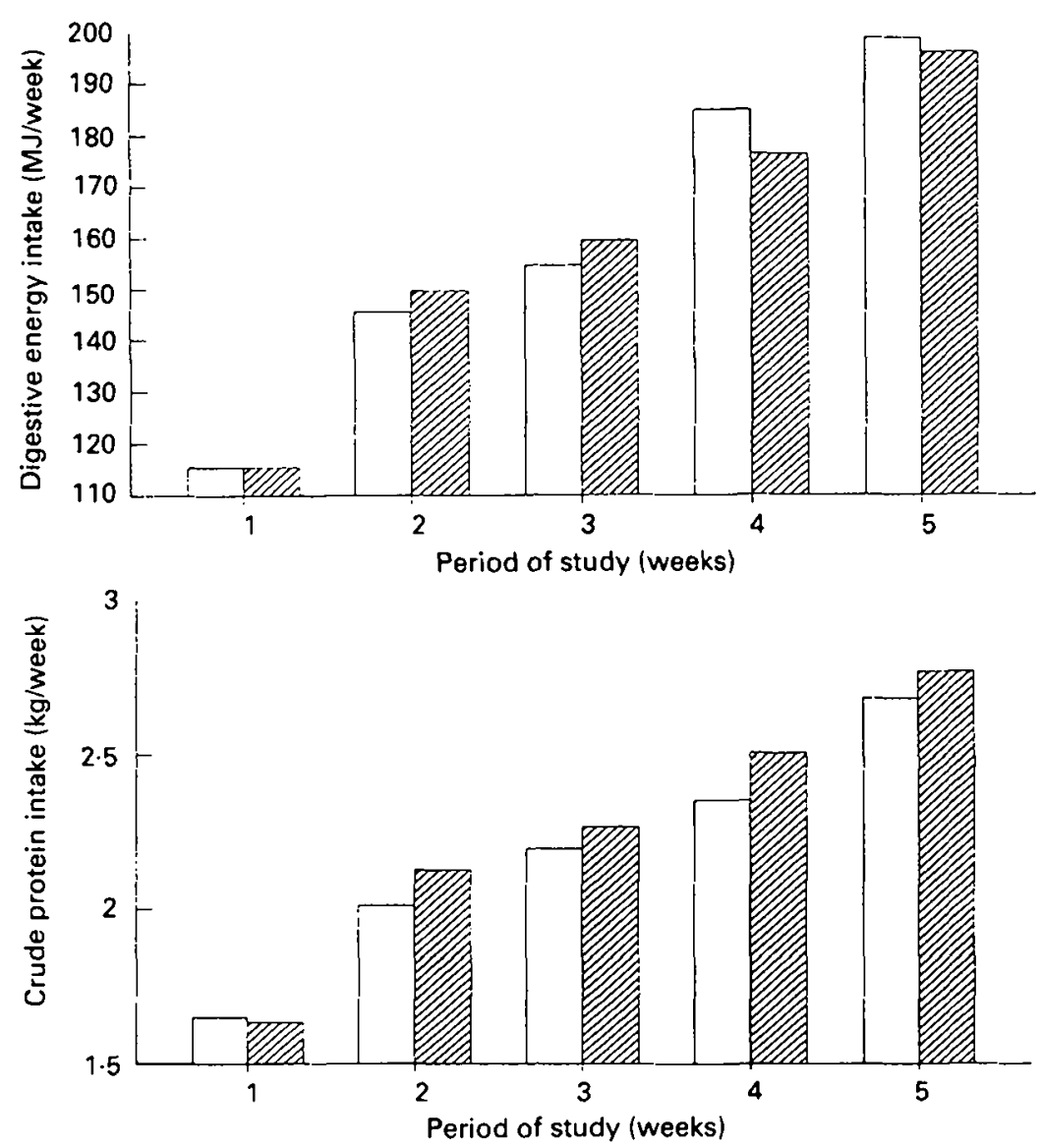

Fig. 1. Crude protein (nitrogen $\times 6 \cdot 25$ ) and digestible energy intakes of choice-fed pigs $(\square)$ and pigs given a single complete feed (因). (From S. P. Rose, unpublished results.)

Leeson \& Summers (1978) gave growing turkeys a choice between a low-protein, high-energy diet and a high-protein, low-energy diet and found that although males and females chose a diet with a similar energy concentration, the faster growing males selected a higher concentration of dietary protein. Similar differences in diet selection between sexes occur in growing broilers (Rose \& Lambie, 1986; Fig. 2). I. Kyriazakis, G. C. Emmans and C. T. Whittemore (unpublished results) observed that growing female choice-fed pigs tended to select a diet with a lower protein concentration than entire male pigs (Table 3 ).

Increased environmental temperatures, which reduce the energy requirements but not the protein requirements of animals, also have predictable effects on their diet selection. Replacement pullets kept at high temperatures and given a choice between a high-energy cereal and a low-energy, high-protein food increased the protein concentration of their overall diet (Rose \& Michie, 1986). Similar dietary selections occur with broilers (Cowan \& Michie, 1977a) and laying hens (Blake et al. 1984). In all these studies, however, the change in the nutrient intakes of the choice-fed birds were not sufficient to overcome the detrimental effects of the high temperatures. 


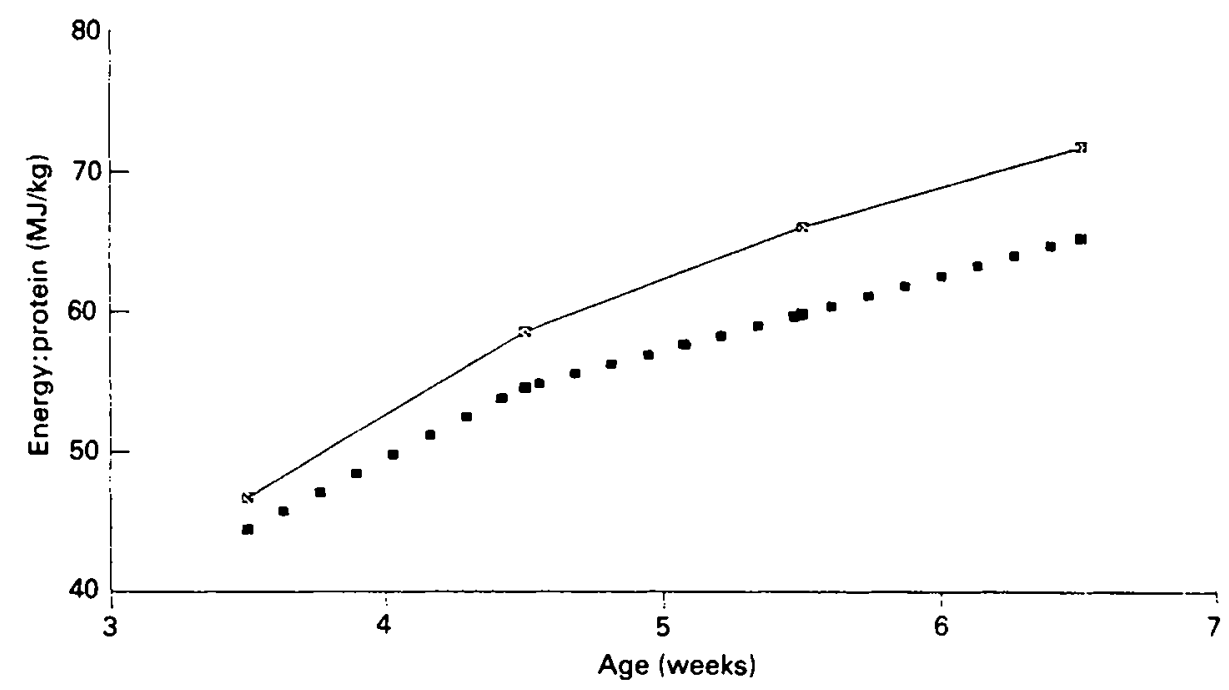

Fig. 2. Nutrient intakes of male ( $\square$ ) and female (- $\-)$ choice-fed broilers. (From Rose \& Lambie, 1986.)

Table 3. The diet selection of fat and lean pigs given two feeds varying in protein concentration (I. Kyriazakis, G. C. Emmans and C. T. Whittemore, unpublished results)

\begin{tabular}{|c|c|c|c|c|}
\hline \multirow[b]{2}{*}{ Sex } & \multicolumn{2}{|c|}{$\begin{array}{l}\text { Proportion of high-protein } \\
\text { food selected } \\
(\mathrm{g} / \mathrm{kg} \text { food intake })\end{array}$} & \multicolumn{2}{|c|}{$\begin{array}{l}\text { Crude protein intake } \\
(\mathrm{g} / \mathrm{kg} \text { food })\end{array}$} \\
\hline & Fat & Lean & Fat & Lean \\
\hline Male & 893 & 405 & 263 & 192 \\
\hline Female & 478 & 169 & 202 & 158 \\
\hline SED & \multicolumn{2}{|c|}{103} & \multicolumn{2}{|c|}{9} \\
\hline
\end{tabular}

SED, standard error of difference.

Previous nutritional status may also alter the nutrient requirements of growing animals. I. Kyriazakis, G. C. Emmans and C. T. Whittemore (unpublished results) made growing pigs relatively fat or thin by giving access to feeds with high or low protein concentrations. Thereafter, both groups of pigs were offered a similar choice between two feeds of high or low protein content (Table 3). Pigs which had been made relatively fat selected a diet with a higher protein concentration compared with the thin group. At the end of the choice-feeding period both fat and thin pigs had selected diets which drew them towards a common body composition, which presumably reflected their inherited genotype.

\section{CHANGING NUTRIENT REQUIREMENTS}

Once the dietary selections of pigs and poultry are established they do not remain static but change systematically, reflecting the changing nutrient requirements of the individuals. Leeson \& Summers (1978) examined the diet selections of growing turkeys from hatching until slaughter and found that as they grew they selected a diet with a 


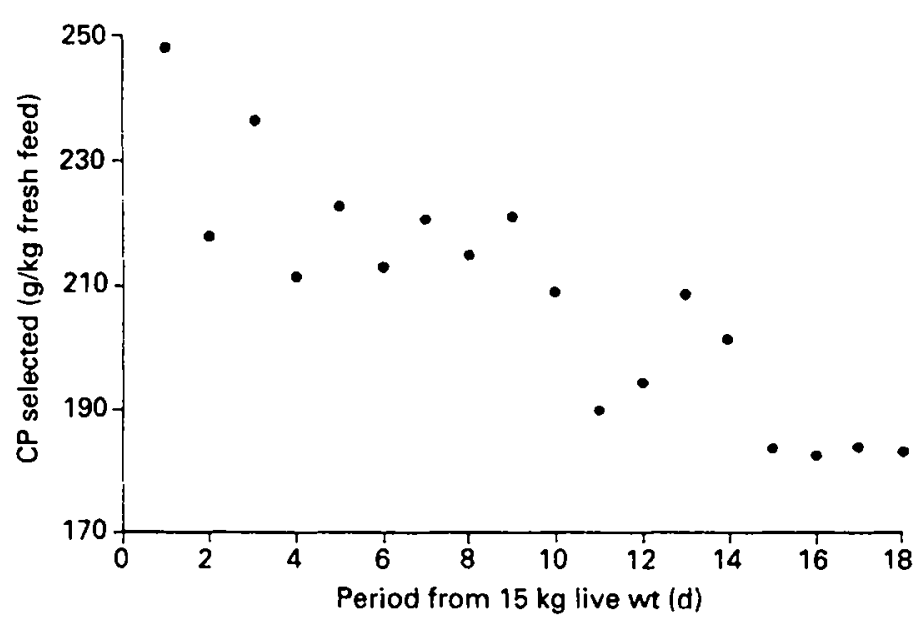

Fig. 3. Crude protein (nitrogen $\times 6.25 ; \mathrm{CP}$ ) selected by choice-fed pigs. (From I. Kyriazakis, unpublished results.)

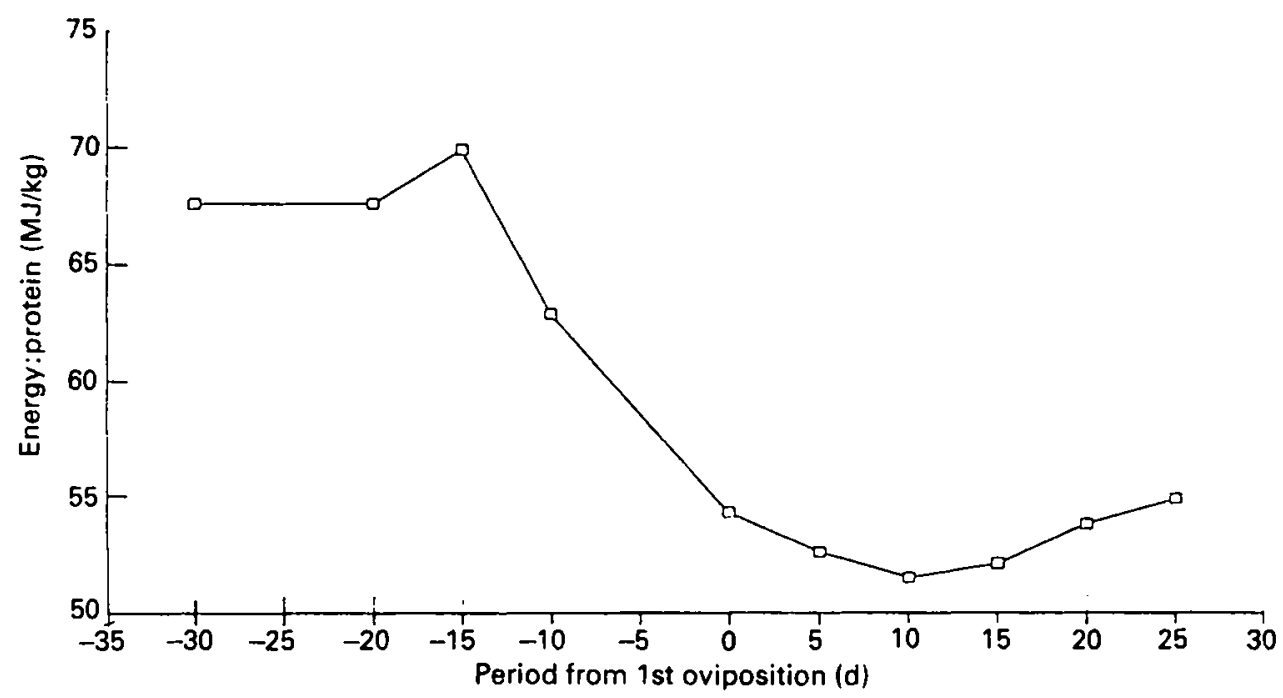

Fig. 4. Nutrient selection of layer strain female chickens. (From Scott \& Balnave, 1989.)

higher energy and lower protein concentration. Similar changes in diet selection were found in broilers (Cowan \& Michie, 1978a). Kyriazakis et al. (1990) examined the diet selection of growing pigs and showed that as they grew they selected a diet with a lower protein concentration (Fig. 3).

Scott \& Balnave (1989) examined the diet selection of choice-fed layer strain pullets during their rearing period and the early part of their laying period. Towards the end of the rearing period, before sexual maturity, the protein concentration of the diet selected by the pullets increased rapidly (Fig. 4). The energy requirement of the birds at this stage 


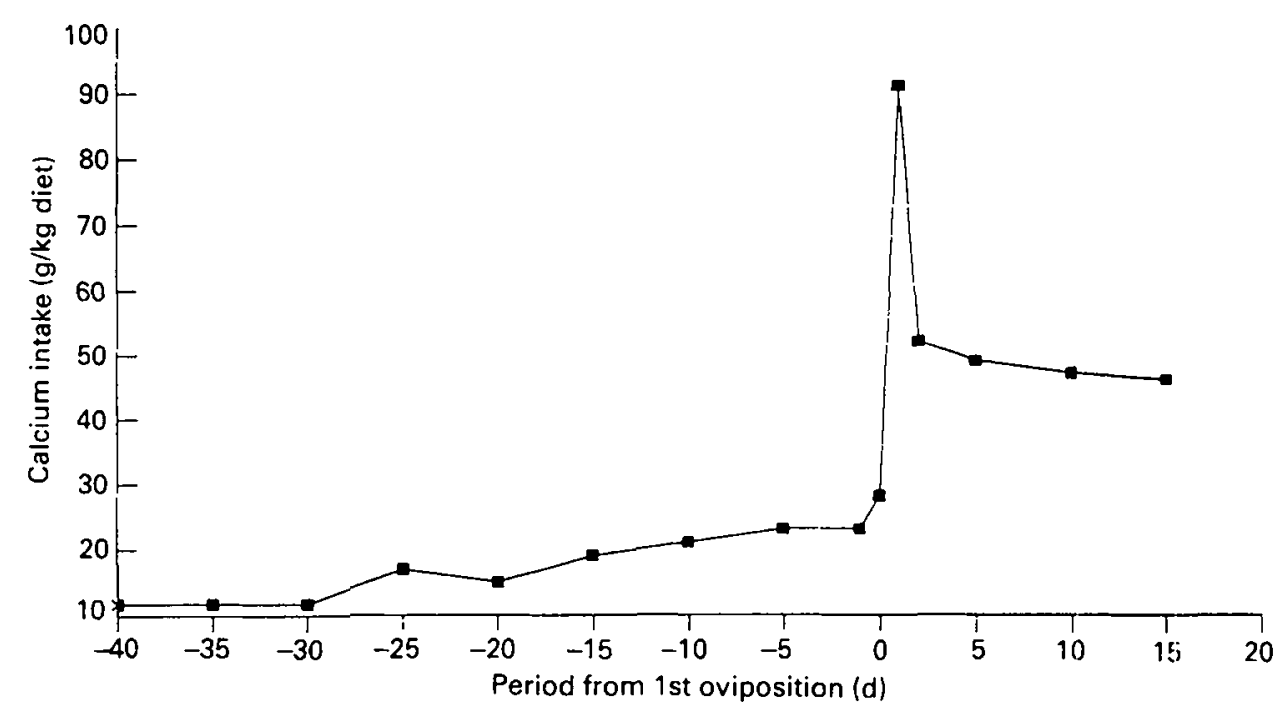

Fig. 5. Calcium selection of layer strain female chickens. (From Classen \& Scott, 1982.)

is low but the rapid development of the oviduct before egg laying would increase their protein demands. Once sexual maturity had been reached the birds selected a diet with a lower protein concentration.

The calcium intakes of layer strain pullets which were given the choice of two feeds which differed in Ca content increased approximately $15 \mathrm{~d}$ before their first oviposition (Classen \& Scott, 1982; Fig. 5). This coincided with the time of Ca storage in sexually immature birds. Although on the day of their first oviposition they had excessively high $\mathrm{Ca}$ intakes, their later $\mathrm{Ca}$ intakes plateaued at a level which met their high requirement for egg production.

\section{OTHER INFLUENCES ON DIET SELECTION}

A number of other factors which are not directly related to balancing nutrient requirements with the nutrient contents of the alternate feedstuffs can also alter diet selections. In some circumstances these influences can have a profound influence on the diet selections of pigs and poultry even though a choice of feeds is ostensibly available for the animal to meet its nutrient requirement.

Broilers given a choice between whole-grain wheat and a high-protein feed select a diet with a higher energy concentration than broilers given a choice between ground wheat and the same high-protein feed (Rose et al. 1986; Fig. 6). The ability of the digestive tract to quickly digest food may explain these findings. Broilers at 3 weeks of age have a relatively small gizzard which would be unable to quickly grind the whole-grain wheat so they initially preferred the ground wheat. However, gizzard size quickly increases when a whole-grain cereal is provided and, thereafter, the whole-grain wheat was preferred because of the speed at which it could be eaten. A similar comparison made with growing pigs showed that those offered the whole-grain wheat chose a slightly higher wheat intake even though this form of wheat has poor availability (S. P. Rose, unpublished results). 


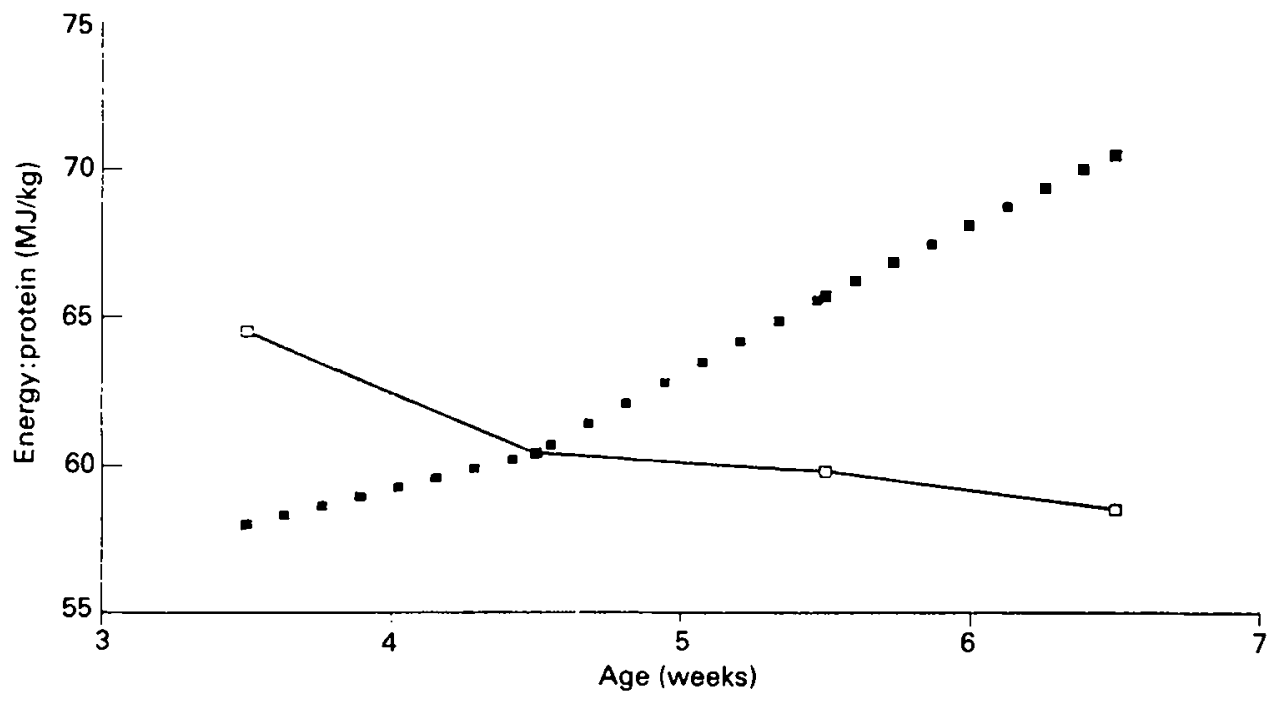

Fig. 6. Nutrient intakes of broilers given a pelleted high-protein feed and ground (- $\square-$ ) or whole-grain wheat. (From Rose et al. 1986.)

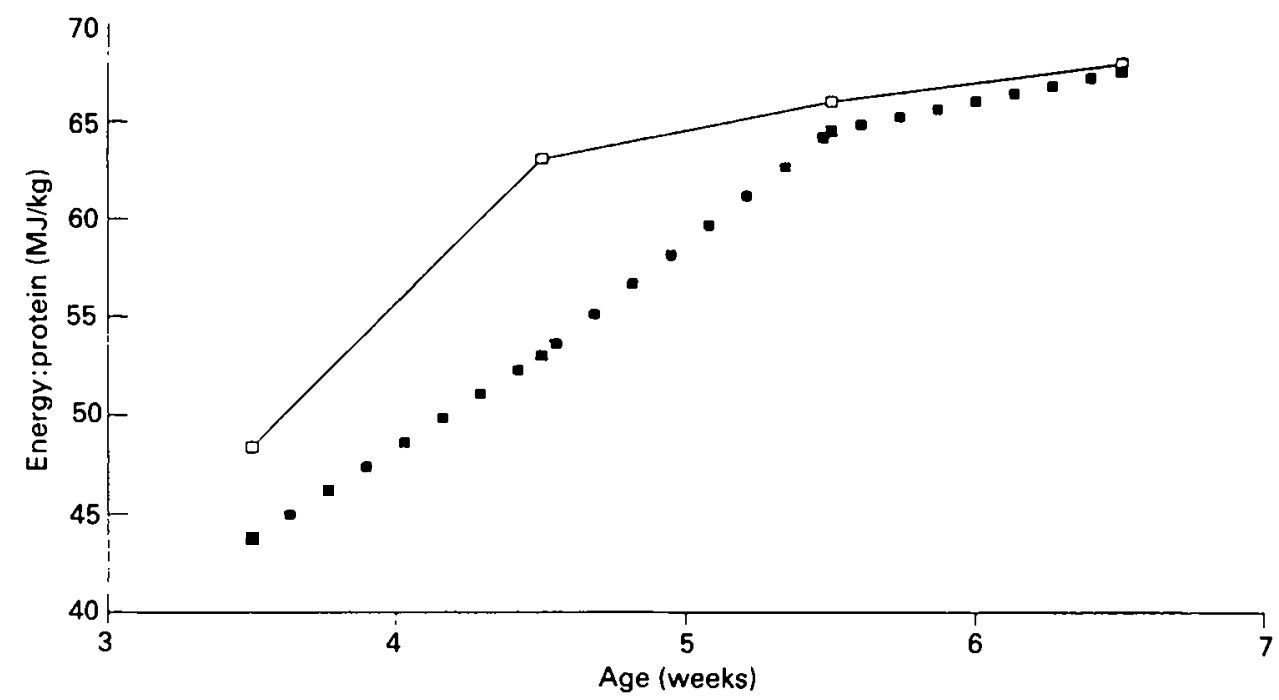

Fig. 7. Nutrient intakes of male and female choice-fed broilers subjected to continuous ( $\square$ ) or intermittent (- $\square-)$ lighting programme. (From Rose \& Lambic, 1986.)

The energy:protein ratio of choice-fed broilers given whole wheat and a high-protein feed was markedly increased in the first week of a choice-feeding regimen when an intermittent lighting programme was given compared with continuous lighting (Rose \& Lambie, 1986). The difference in the diet selections diminished over the length of the growth period (Fig. 7). Scott \& Balnave (1989), however, observed no differences in the diet selections of laying hens kept under continuous or intermittent lighting programmes. In the broiler experiment the birds were given whole cereal which tends to be initially 
avoided by young birds (Savory, 1974) probably because of its difficulty to grind within the gizzard. The intermittent light may have encouraged food storage within the crop in order to maintain a constant supply of food into distal parts of the digestive tract. Food stored within the crop undergoes some gelatinization and so the whole wheat would be easier to grind when it entered the gizzard.

The ability of poultry to quickly digest feedstuffs has been identified as a factor which influences diet selections in a number of other studies. Amar-Sahbi (1987) gave broilers a choice between whole wheat and a high-protein feed. Birds which had access to insoluble grit selected a greater proportion of whole wheat in their diet compared with birds with no supplementary grit. Another treatment gave broilers access to grit for the first 2 weeks only of the 4-week growth period and the initial high cereal intakes of this group were reduced in the final 2 weeks of the experiment. Poultry given feeds containing barley tend to eat less of that feed source than the equivalent feed containing wheat (Cowan \& Michie, 1977b). The high levels of glucans contained in barley reduce the rate of transit of feed within the digestive tract. Addition of $\beta$-glucanase (EC 3.2.1.39) to ground barley significantly increased the selection of this cereal by choice-fed broilers (Rose $\&$ Njeru, 1989).

A characteristic of many choice-feeding experiments is that the diet selection between groups or pens within treatments is highly variable (Farrell et al. 1989). AdretHausberger \& Cumming (1987) offered growing birds a choice of two feeds rich in energy or rich in protein. The diet selection of a group of broilers was determined by a leadership structure. An individual making an unsuitable choice could, therefore, alter the diet selection of the whole pen. However, the leaders within a group were usually those which grew fastest and, thus, over a period of time these individuals would be the birds most likely to be making the correct choice. Rose et al. (1986) kept choice-fed broilers in groups of twenty, forty or sixty with similar stocking densities and feeder space and found no differences in their diet selections over a 4-week period.

A number of feed additives, flavours and colours have been shown to alter the diet selection of pigs (Henry et al. 1985; Edmonds et al. 1987) and poultry (Summers \& Leeson, 1985; Balog \& Millar, 1989). They appear to have little long-term importance in influencing dietary selections. Balog \& Millar (1989) detected preferences for a basal feed with a number of flavours when offered with the basal feed alone. However, these preferences disappeared when the feed troughs were rotated every second day.

\section{THE LEARNING PERIOD}

When two novel feeds are given as a choice, a period of time is necessary for the pigs or poultry to associate the organoleptic properties of the feeds (by using them as cues) with their nutritional consequences. This process has been described by Rozin (1976) as long-delay learning. The time interval which an animal takes to form these associations might be dependent on the number of cues and the nutritional difference of the two feeds offered as a choice. If this learning period forms a significantly large proportion of the test period, then incorrect nutrient intakes during this stage may result in the overall productive performance of the animals being reduced.

Turkeys given a choice of two foods do not start to select a non-limiting diet until 3-4 weeks after the start of the feeding regimen (Cowan \& Michie, 1978b; Leeson \& Summers, 1978). Laying hens which were given a choice of two foods selected an 
energy:protein ratio similar to their published requirements sooner, after the start of the feeding regimen, if they had received a choice-feeding regimen during their rearing period (Cowan \& Michie, 1979). Mastika \& Cumming (1987) gave 3-week-old broiler chicks a choice of whole sorghum and a high-protein food and found that the broilers which had previously experienced a choice-feeding regimen selected a higher energy: protein ratio. Broilers ( 2 weeks old) which were given the choice between a Ca-deficient diet and a separate $\mathrm{Ca}$ source in two experiments took 4 and $6 \mathrm{~d}$ to reach an overall $\mathrm{Ca}$ intake equal to that of broilers given an adequate diet (Joshua \& Mueller, 1979). However, when 4-week-old broilers were housed individually they had a highly variable diet selection with some individuals never reaching an adequate $\mathrm{Ca}$ intake. The relative difference in the nutrient compositions of the various feedstuffs offered and the importance of the other influences on diet selection are probably the major influences on the length of the learning period.

The learning period and the influence of cues is also evident when a choice-feeding regimen is first introduced to pigs (Gous et al. 1989). Some workers have found that it is preferable to speed the learning period by giving access to only one of each of the two feeds on alternate days at the start of the feeding regimen (Gous et al. 1989; Kyriazakis et al. 1990). In an experiment when the feed-trough positions of two feeds were reversed after 3 weeks on a choice-feeding regimen the correlation between the amount of a feed selected on each day of the days following the change and the amount of this feed selected the week before increased over time: from $r 0.754$ for the first day to $r 0.908$ for the seventh day (Kyriazakis et al. 1990).

\section{USE OF DIET-SELECTION TECHNIQUES}

Study of the diet selection of pigs and poultry has value in understanding the nutrient requirements of that class of stock. Sinurat \& Balnave (1986) have used this technique to give recommendations on diet specifications for broilers reared at high temperatures. Rapid advances are now being made in breeding commercial strains of pigs and poultry. Diet-selection techniques could be used to quickly assess any possible changes in the nutrient requirements of these strains.

A feeding system which allows a limited choice of two or three feedstuffs can also be adopted in commercial pig and poultry enterprises. Most of these development studies have adopted a two-food choice where one feed is whole cereal. A number of comparisons have been made between choice-feeding and single complete-feed systems. In summary, the productive performance of choice-fed laying hens is equal to or slightly better than that of hens given complete feeds, but their total food intakes tend to be high sometimes causing a poorer food conversion efficiency. Choice-fed growing turkeys have similar growth rates to birds given complete feeds, although again the feed conversion efficiency is sometimes inferior. The live-weight gains of choice-fed broilers are approximately $10 \%$ lower than those of birds given complete feeds. Structuring the production system to give cues which encourage a rapid learning period may be the way in which the overall performance of choice-fed broilers can be improved. A study in which an intermittent lighting programme and fat addition to the cereal were used gave similar productive performances of broilers either choice-fed or given a complete single feed (Rose \& Lambie, 1986). Choice-feeding comparisons with growing pigs have shown similar productive performance to a complete-feed system. Engelke et al. (1984) and 
Gous et al. (1989) have reported similar performance of pigs grown to heavy slaughter weights when compared with pigs given complete single feeds.

The major economic advantage of a choice-feeding regimen for commercial pig and poultry production systems is a reduction of protein use. Growing broilers and pigs, after the brooding and weaning stages respectively, may only be given two different single feeds up to their slaughter weight. Assuming that the protein requirements of growing animals decrease regularly as maturity increases, after the time that a new feed is introduced the animals given a single-feed system must overeat dietary protein until the next feed is introduced. If choice-fed pigs and poultry reduce their protein intake gradually over the whole growth period then this would result in a saving of approximately $5 \%$ of the total protein intake of pigs given a two single-feed programme over this period.

Many pig and poultry units do not feed males and females separately, although, for example, female broilers require diets with a lower protein concentration than males (INRA, 1984). As choice-fed females select a lower dietary protein concentration than males, the extra saving in dietary protein amounts to a further $2.5 \%$ of the protein usage. Often poor-quality housing or the production system do not always allow ambient temperatures to be kept at an optimum. Animals kept below their lower critical temperature and given a single-feed system thus overeat protein in order to meet their increased energy demands. If a flock of broilers were kept at $5^{\circ}$ below the optimum temperature or pigs kept at $5^{\circ}$ below their lower critical temperature then the choice-fed animals, which would only increase their intake of the high-energy cereal feed, would eat approximately $1.5 \%$ less protein over their growth period.

A feed delivery system which is capable of storing and conveying two separate feeds is necessary in order to implement a choice-feeding regimen in a large-scale production system. The cost of this can often be prohibitive when assessing the value of a choice-feeding regimen. It is probable that choice-feeding systems will only become financially attractive to large pig and poultry enterprises at times when the cost of protein is high relative to the cost of energy.

\section{REFERENCES}

Adret-Hausberger, M. \& Cumming, R. B. (1987). Social experience and selection of diet in domestic chickens. Bird Behaviour 7, 37-43.

Ahmed, Z. (1984). Citcd by Rose, S. P. (1984). Reducing feeding costs of growing poultry through choice-feeding: A summary of recent experiments. Scottish Agricultural Colleges Research and Development Note no. 20. Aberdeen: Scottish Agricultural College.

Amar-Sahbi, R. (1987). The diet selection of female broilers. MSc Thesis, University of Aberdeen.

Balog, J. M. \& Millar, R. I. (1989). Influence of the sense of taste on broiler chick feed consumption. Poultry Science 68, 1519-1526.

Blakc. A. G.. Mather, F. B. \& Gleaves, E. W. (1984). Dietary self-selection of laying hens inadequate to overcome the effects of high environmental temperature. Poultry Science 63, 1346-1349.

Brody, T. B.. Cherry, J. A. \& Siegel. P. B. (1984). Responses to dietary self selection and calories in liquid form by weight selected lines of chickens. Poultry Science 63, 1626-1633.

Classen, H. L. \& Scott. T. A. (1982). Self-selection of calcium during the rearing and early laying periods of white leghorn pullets. Poultry Science 61, 2065-2074.

Cowan, P. J. \& Michie. W. (1977a). Environmental temperature and choice feeding of the broiler. British Journal of Nutrition 40, 311-315.

Cowan, P. J. \& Michie, W. (1977b). Choice feeding of the turkey: Use of a high-protein concentrate fed with either whole wheat, barlcy, oats or maize. Zeitschrift für Tierphysiologie, Tierernährung und Futtermittelkunde 39, 124-130: 
Cowan, P. J. \& Michie, W. (1978a). The use of barley in choice feeding of the turkey. British Poultry Science $19,1-6$.

Cowan, P. J. \& Michie, W. (1978b). Choice feeding of the male and female broiler. British Poultry Science 19, 149-152.

Cowan, P. J. \& Michie, W. (1979). Choice feeding of the fowl during rearing and lay. World Review of Animal Production 15, 47-50.

Dawkins, R. (1989). The Selfish Gene. Oxford: Oxford University Press.

Edmonds, M. S., Gonyou, H. W. \& Baker, D. H. (1987). Effect of excess levels of methionine, tryptophan, arginine, lysine or threonine on growth and dietary choice in the pig. Journal of Animal Science 65, $179-185$.

Engelke, G. L., Jurgens, M. H. \& Speer, V. C. (1984). Performance of growing-finishing swine fed high-moisture or artificially dried corn in complete and free-choice diets. Journal of Animal Science $\mathbf{5 8 .}$ $1307-1312$.

Evvard, J. M. (1915). Is the appetite of swine a reliable indication of its physiological needs? Proceedings of the Iowa Academy of Science 22, 375-403.

Farrell, D. J.. Ball, W., Thompson. E., Abdelsamie. R. E. \& Pesti, G. M. (1989). How well do layers discriminate given choices of grain and protein concentrate? In Recent Advances in Animal Nutrition in Australia 1989, pp. 311-321 [D. J. Farrell, editor]. Armidale, Australia: University of New England Publishing Unit.

Gous, R. M., Bradford, M. M. V. \& Kobus, G. E. (1989). Choice fecding experiments with growing pigs. In Recent Advances in Animal Nutrition in Australia 1989, pp. 147-154 [D. J. Farrell, editor]. Armidale, Australia: University of New England Publishing Unit.

Henry, R. W., Pickard, D. W. \& Hughes, P. E. (1985). Citric acid and fumaric acid as food additive for early-weaned piglets. Animal Production 40, 505-509.

Holcombe. D. J., Roland, D. A. \& Harms, R. H. (1976). The ability of hens to regulate protein intake when offered a choice of diets containing different levels of protein. Poultry Science 55, 306-317.

INRA (1984). Feeding of Non-Ruminant Livestock [J. Wiseman, cditor]. London: Butterworths.

Joshua, I. G. \& Mueller, W. J. (1979). The development of a specific appetite for calcium in growing broiler chicks. Poultry Science 20, 481-490.

Kiiskinen, T. (1987). Influence of choice feeding on the performance of growing pullets and laying hens. Annales Agriculturae Fenniae 26, 131-144.

Krebs, J. R. \& Davies, N. B. (1981). An Introduction to Behavioural Ecology. Oxford: Blackwell.

Kyriazakis, I., Emmans, G. C. \& Whittemore, C. T. (1990). Diet selection in pigs: Choices made by growing pigs given feeds of different protein contents. Animal Production 51, 189-200.

Leesun, S. \& Summers, J. D. (1978). Dietary self-selection by turkeys. Poultry Science 57, 1579-1585.

Mastika, M. \& Cumming, R. B. (1987). In Recent Advances in Animal Nutrition in Australia 1987, pp. 260-282 [D. J. Farrell, editor]. Armidale, Australia: University of New England Publishing Unit.

National Research Council (1984). Nutrient Requirements of Poultry, 8th ed. Washington: National Academy Press.

Rose, S. P., Burnett, A. \&. Elmajeed, R. A. (1986). Factors affecting the diet selection of choice-fed broilers. British Poultry Science 27, 215-224.

Rosc, S. P. \& Lambie, I. T. M. (1986). Comparison of a choice-feeding regimen for broilers under continuous and intermittent lighting programmes. Proceedings of the 7 th European Poultry Conference, Paris, pp. 903-906. Tours, France: World's Poultry Science Association.

Rose, S. P. \& Michie, W. (1982). The food intakes and growth of choice-fed turkeys offered balancer mixtures of different compositions. British Poultry Science 23, 547-554.

Rose, S. P. \& Michie, W. (1986). Effect of temperature and diet during rearing of layer strain pullets. In Nutrient Requirements of Poultry and Nutritional Research. Poultry Science Symposium no. 19, pp. 214-216 [C. Fisher and K. N. Boorman, editors]. London: Butterworths.

Rose, S. P. \& Njeru, F. N. (1989). Effect of enzyme supplementation of cereals on the diet selection of choice-fed broilers. British Poultry Science 27, 975-976.

Rozin, P. (1976). The selection of foods by rats, humans, and other animals. In Advances in the Study of Behaviour, vol. 6 [J. S. Rosenblatt, R. A. Hinde, E. Shaw and C. Beer, editors]. New York: Academic Press.

Savory, C. J. (1974). Growth and behaviour of chicks fed on pellets or mash. British Poultry Science 15, $281-286$. 
Savory, C. J. (1979). Cited by Hughes, B. O. (1979). In Food Intake Regulation in Poultry, pp. 141-169 [K. N. Boorman and B. M. Freeman, editors]. Edinburgh: British Poultry Science Ltd.

Scott, T. A. \& Balnave, D. (1989). Responses of sexually-maturing pullets to self-selection fceding under different temperature and lighting regimes. British Poultry Science 30, 135-150.

Sinurat, A. P. \& Balnave. D. (1986). Free-choice feeding of broilers at high temperatures. British Poultry Science 27, 577-584.

Summers, J. D. \& Leeson, S. (1985). Self-sclection by laying hens of diets differentiated by texture and color. Poultry Science 64. 411-413. 